\title{
Globalization and the rise of integrated world society: deterritorialization, structural power, and the endogenization of international society
}

\author{
Salvatore Babones ${ }^{1}$ and John H. S. Aberg ${ }^{2 *}$ (i) \\ ${ }^{1}$ Department of Sociology, University of Sydney, Sydney, Australia and ${ }^{2}$ Department of Global Political \\ Studies, Malmö University, Malmö, Sweden \\ ${ }^{\star}$ Corresponding author. Email: john.aberg@mau.se
}

(Received 29 November 2018; revised 24 March 2019; accepted 1 July 2019)

\begin{abstract}
There is a widespread feeling that globalization represents a major system change that has or should have brought world society to the forefront of international relations theory. Nonetheless, world society remains an amorphous and undertheorized concept, and its potential role in shaping the structure of the international society of states has scarcely been raised. We build on Buzan's $(2018,2)$ master concept of 'integrated' world society ('a label to describe the merger of world and interstate society') to locate the integration of world society in the globalization of social networks. Following the advice of Buzan (2001) and Williams (2014), we use conceptual frameworks from international political economy to systematically explore the structure of integrated world society along six dimensions derived from Mann (1986) and Strange (1988): military/security, political, economic/production, credit, knowledge, and ideological. Our empirical survey suggests that, on each of these dimensions, power has centralized as it has globalized, generating steep global hierarchies in world society that are similar to those that characterize national societies. The centrality of the United States in the networks of world society makes it in effect the 'central state' of a new kind of international society that is endogenized within integrated world society.
\end{abstract}

Keywords: world society; english school; power; international society; globalization; networks

\section{Introduction: evolving conceptualizations of world society}

Globalization has changed the human world in myriad ways, but it has done relatively little to change international relations theory's focus on the state. After all, 'national' is in the very name of the discipline. At its core, international relations theory is still 'an area of study concerned with the interrelationships among states in an epoch in which states, and most commonly nation-states, are the principal aggregations of political power' (Cox, 1981, 126). Like other contemporary approaches to international relations, the 'English School' approach associated reproduction in any medium, provided the original work is properly cited. 
with Bull (1977), Wight $(1977,1992)$, and Buzan (2004, 2014a) tends to be ontologically state-centric (Devlen, James, and Ozdamar, 2005, 176), yet English School scholars have long sought to supplement the study of the international system of competing states with the study of a 'second-order' society of states under the rubric of 'international society' (Buzan, 2014a, 12-15). This research program is now well-developed and intellectually well-elaborated, and has entered the mainstream of the discipline (Buzan, 2004, 2014a).

English School scholars have also pioneered the theorization of 'world society' in international relations. In its English School conceptualization, world society is not a second-order society of societies but a first-order society of individual human beings (Buzan, 2014a, 15) that, together with the international society of states, constitute a whole society of human institutions (Albert and Buzan, 2013). The English School understanding of world society is similar to that pioneered by Meyer et al. (1997) and the 'Stanford School' in sociology, who characterize world society as 'stateless' $(145,169)$ and 'mainly made up of what may ... be called 'rationalized others': social elements such as the sciences and professions ... that give advice to nation-state and other actors about their true and responsible natures, purposes, technologies, and so on' (162). Buzan ranks world society among the core concepts of the English School, maintaining that 'the foundation of English School theory is the idea that international system, international society and world society all exist simultaneously,' but in Buzan's view, 'world society has been the Cinderella concept of English School theory, receiving relatively little attention and virtually no conceptual development' (Buzan, 2004, 10-11). He emphasizes that 'if, as many people think, the world society element is rising in significance, this neglect becomes untenable' (Buzan, 2004, 10-11).

If that was true then, it is even more true now. Four decades ago, Cox $(1981,149)$ already saw in the 'internationalization of production' the 'prospect for a new hegemony being based upon the global structure of social power.' Today, such global structures of social power are thick on the ground, yet international relations theory continues to underappreciate their potential to influence the structure of international society and the international system. As Buzan $(2004,11)$ suggests, in the pre-globalization era it may have been reasonable for international relations theory to treat world society as a 'residual element in the background.' No longer. If Bull (1977, 279-280) could admit forty years ago the importance of 'the development of global communications creating an unprecedented degree of mutual awareness among different parts of the human community,' then how much more is this true today? Bull $(1977,280)$ doubted that the level of global 'interdependence' fostered by the communication networks of the 1970s was sufficient to support a true world society, but the social web, free global telecommunications, mass immigration, and frequent air travel seem to have put paid to that notion. In the twenty-first century, the technical feasibility of world society, if not already assured, soon will be.

Though understandings of world society in international relations are multifarious and contested, we think it is useful to turn to Bull's account in The Anarchical Society as a touchstone, both because it is so widely known and because it predates the globalization era. It thus represents a kind of theoretical vision of world society from a time before world society became a practical everyday reality in all our lives. Whatever degree or amount of world society that existed in 1977, more of it exist 
today. Bull (1977) classically sought to give shape to the concept of world society by way of analogy to the better-established concept of international society:

'By a world society we understand not merely a degree of interaction linking all parts of the human community to one another, but a sense of common interest and common values on the basis of which common rules and institutions may be built. The concept of world society, in this sense, stands to the totality of global social interaction as our concept of international society stands to the concept of the international system' (Bull, 1977, 279).

Here Bull argues that for world society to be taken seriously it must in some sense shape the behavior of individuals in global interaction networks in the same way that the international society of states shapes the behavior of states in the international state system. World society, thus construed, could then be observed in the emergence of 'common interest and common values' that could form the basis for the development of 'common rules and institutions.' Parsing Bull's presumably unintentional but nonetheless highly influential test for the discovery of world society, one might look for evidence of (1) global interaction networks that (2) align people's interests and values in ways that (3) give rise to shared values and institutions.

In this paper we build on Bull's prescient insights from the pre-globalization era to attempt to fit empirical slippers to Buzan's Cinderella concept. We begin by further clarifying the concept of 'world society' and its relationship to international society. We then identify six global interaction networks in which individuals are embedded in power relations that have the potential to influence their behavior (or to empower them to influence the behavior of others). We find that these networks do align people's interests and values on a global scale, but not in the cosmopolitan directions assumed by most contemporary English School theorists. We find instead that the networks of world society tend to align individuals hierarchically, and that their peak nodes are overwhelmingly located in or associated with the United States, which exhibits a level of centrality in world society that is disproportionate even to its (still large) shares of global population, military power, and GDP. World society has thus given rise, we argue, to a new form of international society: a central state system. We conclude with a reformulation of the English School framework that suggests that world society has the potential to give order to international society, just as international society has itself brought order to the international system.

\section{The primary institutions of (integrated) world society}

Buzan (2018) identifies three different meanings of the term 'world society' as it is used in the international relations literature. He labels these normative world society, political world society, and integrated world society. Normative world society is concerned with the ethics of humanity qua humanity, the emerging and evolving set of near-universal global political norms. A clear example of a world society behavioral norm is that against slavery (Clark, 2007). This does not mean that slavery has been eradicated, but it does mean that slavery is so widely condemned as to 
persist only on the margins and in the shadows of today's world. Political world society is concerned with non-state transnational political activity. The archetype of political world society is the international non-governmental organization (INGO) (Boli and Thomas, 1997). Along with (and often through their influence on) intergovernmental organizations, INGOs participate in shaping the contours of international society, for example in achieving the formal proscription of slavery in international law.

Buzan's third meaning of 'world society' is integrated world society. Integrated world society is an amorphous but ultimately unifying and binding concept that has the potential to endogenize international society and its relationships to normative and political world society under a single conceptual umbrella. It is the true 'Cinderella' meaning of world society, the one for which we have the shoe but lack the foot. In Buzan's telling:

'The first two meanings of world society are based on separating the interstate domain from both the interhuman/normative one, which serves as its normative reservoir, and the transnational/political one, which serves as the activist lobby intermediating between normative world society and interstate society. Integrated world society brings all three domains under one umbrella, creating an ideal-type for a prospective future' (Buzan, 2018, 6).

He further suggests that integrated world society would eliminate the primacy of the state over individuals and organizations, or at least make individuals and organizations 'subjects of international law in their own right' (Buzan, 2004, 203; $2018,14)$. Here we believe Buzan misses the mark. International law is a creature of international society; an integrated world society that endogenized international society would ipso facto endogenize international law. In other words, it is enough to identify an integrated world society that governs international law, even if it does not raise individuals and organizations to the legal status of states.

Buzan (2018) identifies the key primary institutions of normative and political world society as 'collective identity' (p. 9) and 'advocacy' (p. 11), respectively. On the model of the term 'collective identity,' a parallel term for the key primary institution of political world society might be 'organized representation,' a construction that reflects the fact that advocacy in world society almost always involves formal organizations and that those organizations seek (whether successfully or not) to represent constituencies (real or imaginary). Even the most powerful people in the world seem to find it appropriate and necessary to participate in world society through organizations that purport to represent the interests of others (e.g., the Bill \& Melinda Gates Foundation). Framed in this manner using the formula of abstract nouns preceded by a qualifying adjective, collective identity and organized representation in world society correspond to 'territorial sovereignty' as the key primary institution of international society. Each of these terms embodies a principle of legitimacy and a principle of differentiation. For international society, sovereignty legitimates the state while territoriality differentiates states from each other. For normative world society, people's self-identification as belonging to a particular social group legitimates group solidarity, while people's membership in specific groups differentiates those groups from each other; for political world 
society, representation legitimates the agency of advocates, while organization differentiates activist movements.

Buzan (2018) does not identify a key primary institution for integrated world society, though he does suggest three domains in which the primary institutions of integrated world society might operate: top-down from international society into political and normative world society, bottom-up from political and normative world society into international society, and among units of all types to establish their rights and responsibilities vis-a-vis each other (Buzan, 2018, 12). The third, of course, is the key to the puzzle. It construes individual human beings as direct participants in world society. This represents a return to the classic English School roots of the concept. In Buzan's (2001) telling:

'It is clear that the relationship between international society and world society is fundamental to English School theory ... [but] the concept of world society remains seriously underspecified, in some ways resembling the theoretical dustbin that neorealists made of the unit level. In an ontological sense, world society starts from individuals and is in clear contrast to the state-based ontology of international society' (Buzan, 2001, 477).

Later Buzan (2004, 44) clarifies that this 'analytical dustbin, uncomfortably containing revolutionism, cosmopolitanism and transnationalism' is a catch-all for Wight's $(1992,41)$ three paths to the 'assimilation' of 'international relations to a condition of domestic politics.' It is precisely this dustbin to which we propose to return. Wight's political cosmopolitanism evokes a 'world society of individuals which overrides nations or states' (Buzan, 2004, 34 quoting Wight, 1992, 45).

In Buzan's (2004, 34-35) analysis, the 'cosmopolitan scenario is closest to current understandings of world society, but sits in unreconciled tension with Wight's argument that shared cultures have to underpin international societies.' We see no tension here, because we put no preconceived content into the Wightian container of Kantian cosmopolitanism. Wight may have identified cosmopolitanism with the name of Kant (fair enough), but he identified Hitler and Stalin as Kantians alongside Wilson and Mazzini (Wight, 1992, 160). The assumption that a cosmopolitan shared culture must be based in moral justice, so strong in Bull $(1977,80-82)$, is in our view the root error that has generated much of the confusion that plagues the study of world society today.

Nor do we take for granted Wight's $(1992,161)$ own assumption that an actually existing world society would necessarily embrace a Kantian vision of universal solidarism. This is to assume that a society must (as opposed to should) exhibit a solidarity that embraces all of its members, an assumption that is blatantly at odds with the historical reality of slavery, racialization, patriarchy, colonialism, and other forms of subjugation within actually-existing societies. In searching for the primary institutions of actually existing world society, we turn instead to Buzan's (2018) more organic approach to identifying world society institutions:

'What can be said is that whatever principles of differentiation and legitimacy were agreed amongst the different types of actors would almost certainly become primary institutions of an integrated world society' (Buzan, 2018, 14). 
Legitimacy has always been a slippery concept. Though moral philosophers may never agree on what constitutes a basis for legitimacy in world society, in practice actually-existing world society institutions have adopted various forms of the tripartite mantra of democracy, human rights, and the rule of law. Enshrined in the United Nations (2000) Millennium Declaration, democracy, human rights, and the rule of law are now routinely cited as the ideological foundation of world society. For example, the world society journal Global Constitutionalism was launched with an essay that seemingly defined global constitutionalism using these three concepts (Wiener et al., 2012), and though the editors later pulled back from that idealistic position (Tully et al., 2016), the ideal remains. Democracy, human rights, and the rule of law (in particular the fundamental writ of habeas corpus) are all premised on the more general principle of individualism: the idea that individual self-determination outweighs all but the most pressing demands of the group. For whatever reasons (and the reasons are highly contentious), from the perspective of the twenty-first century it seems clear that individualism has won out over communitarian ideologies as the legitimating principle of world society. Thus whereas modern nationalisms (plural) have often taken it for granted that the state has the right (and even the responsibility) to interfere in personal domains of behavior like sexual orientation, abortion rights, drug use, religious practice, and suicide, postmodern individualism (singular) increasingly places such behaviors in the realm of individual self-determination. But individualism alone is not enough: a functioning society (world or otherwise) is more than just a collection of atomized individuals. Individuals must somehow be bound together to form a society. To date, both the English School and Stanford School literatures have tended to focus on international NGOs as the binding elements of world society, but very few people actually participate in such organizations. Many more people are globally connected through economic networks of work and consumption. And nearly everyone participates in online social networks and offline personal relationships that increasingly span the entire world.

Transnational networks serve both to integrate and to differentiate the participants in world society in relation to each other. We thus identify the key primary institution of integrated world society as 'networked individualism': an institution that has individualism as its principle of legitimacy and the network structure as its principle of differentiation. In Table 1 we place this alongside the principles of legitimacy and differentiation of other types of society, starting with the national societies that emerged and evolved in symbiosis with the international system itself.

Following Buzan (2018), we see integrated world society as a system that subsumes international society, normative world society, and political world society (and, by extension, the international system ad national societies as well). We describe the interaction networks of world society 'deterritorialized' because although their physical nodes must in extremis exist within states, the networks as such do not (Agnew, 1994).

Whether and to what degree deterritorialized networks really do function to connect and differentiate individuals is an empirical question, but an obvious answer to this question is 'more than ever before.' It is probably no coincidence that Clark (2007) dates the emergence of normative world society to the early 19th century, a period when technology was just beginning to dramatically shorten 
Table 1. Principles of legitimacy and differentiation in international and world society

\begin{tabular}{lll}
\hline Form of society & Principle of legitimacy & Principle of differentiation \\
\hline National society & Citizenship & Personhood \\
\hline International society & Sovereignty & Territoriality \\
\hline Normative world society & Identification & Collective membership \\
\hline Political world society & Representation & Organization \\
\hline Integrated world society & Individualism & Network structure \\
\hline
\end{tabular}

communication times, and Boli and Thomas (1997) show that political world society expanded dramatically following World War II, a time when air travel and global telecommunications finally made it practical to manage integrated (as opposed to merely affiliated) international NGOs. As technology has developed, the dramatic increases in the bitrate of global communication networks have made possible the formation of an integrated world society today.

In the 2000s, of course, 'the technological unification of the world' (Bull, 1977, 273-276) is taken for granted. The transnational density of today's communication networks clearly meets Bull's $(1977,279)$ world society criterion of a 'degree of interaction linking all parts of the human community.' They also seem to us likely to establish Bull's more important 'common interest and common values on the basis of which common rules and institutions may be built,' though this is an empirical question that we will investigate. Thus in the next section we develop a more systematic framework for identifying the transnational structures that have the potential to translate global interaction into common rules and institutions of integrated world society, from which we then derive the outlines of world society as it actually exists today.

\section{Structural power in the deterritorialized networks of world society}

In this section, we take an analytical approach to identifying a set of domains over which world society may be said to function. Cox $(1981,126)$ characterized the pre-globalization era as one in which states 'are the principal aggregations of political power,' and indeed this can be taken as the primary reason why the field of international relations has the name it does. The shift in focus from international to world society thus raises the question: what are the principal aggregations of power in world society? To aid in operationalizing the power networks of world society, we turn to the international political economy (IPE) literature, which has long engaged with the study of global power networks and has developed highly-refined, empirically-supported approaches to categorizing them. We thus follow Buzan's (2001, 485) suggestion that a 'compelling case can be made for integrating English School theory and IPE.' Williams $(2014,137)$ similarly suggests that an IPE perspective 'can contribute to historical and comparative analyses of the impact of global-level activity, global-based justificatory strategies, and global institutional innovations' on 'world society's interhuman and transnational elements.' A major advantage of IPE theory for our purposes is that IPE scholars like Mann (1986) and 
Strange (1988) have explored and specified the transnational networks through which power is exercised in international (and by extension world) society. International relations scholars, by contrast, have tended to theorize functional domains in world society without offering specific proposals for how they can be practically operationalized. For example, only one of Schouenborg's (2011) five functional categories for primary world society institutions, 'trade' (including production for exchange), could easily be operationalized. His other four categories, and the additional functional categories he identifies in the work of Buzan (2004) and Bull (1977), would be very difficult to study empirically in the context of a single research paper.

In our empirical analyses of the power networks of world society, we turn for inspiration primarily to the work of Susan Strange and Michael Mann. Mann $(1986,1)$ claims that societies 'are constituted of multiple overlapping and intersecting sociospatial networks of power' (emphasis in the original) and locates the 'sociospatial capacity for organization' (Mann, 1986, 3) of societies in these power networks. If world society is indeed a national society writ large, or a society of any kind at all, then an IPE perspective on world society might suggest that it is characterized by sociospatial power networks that link (and in many cases subordinate) individuals on a global scale. We see no reason to assume that actually-existing world society is non-hierarchical. Quite the contrary. If we are correct that the legitimating principle of national society is citizenship while that of world society is individualism, then we would expect power differentials in world society to be relatively less fettered than those exhibited by national societies, where citizenship rights at least to some degree moderate the differentials between individuals. On at least one important indicator, the distribution of individual income, world society is in fact much more unequal than national societies: the global Gini coefficient of around 0.7 (Milanovic, 2012, 9) is higher than that of any country in the world today.

Mann's 'overlapping and intersecting sociospatial networks of power' imply a high degree of structure, but structure does not exist solely (or even primarily) in formal organizations. It exists in social networks as well. We follow Strange in believing power derived from advantageous positions in structural networks is at least as important as the visible relational power of one actor over another in formal organizational hierarchies. Strange herself defined structural power in quite statist terms as:

'the power to shape and determine the structures of the global political economy within which other states, their political institutions, their economic enterprises and (not least) their scientists and other professional people have to operate' (Strange, 1988, 24-25).

We propose to remove the 'states' and the possessive 'their' from this definition, in order to generalize Strange's concept of structural power from the international society with which she was concerned to the world society setting that is the focus of this article. Thus following Strange we think of structural power in world society as 'the power to shape and determine the structures of the global 
political economy within which other actors, political institutions, economic enterprises and (not least) scientists, and other professional people have to operate.'

For Strange (1989, 165), structural power 'embraces customs, usages, and modes of operation,' whereas relational power 'stays closer to state-state agreements and state-centered institutions.' There is a clear parallel here with the contrast between world society and international society. Strange apparently did not theorize this distinction, but it is nonetheless implicit in her writing. She wrote that structural power 'confers the power to decide how things shall be done, the power to shape frameworks within which states relate to each other, relate to people, or relate to corporate enterprises' (Strange, 1988, 25).

Strange $(1988,24-32)$ identified four 'structures' of power in what we would call world society: security, production, finance, and knowledge. Mann $(1986,2)$ similarly identifies a set of four important 'sources of social power' that he characterizes as 'overlapping networks of social interaction' (emphases in the original): ideological, economic, military, and political. Obviously, these two schemas overlap substantially, though not completely. We propose to amalgamate them into a set of six important power networks (Table 2): the military/security, political, economic/production, credit, knowledge, and ideological networks of power in world society. We place these six networks on a continuum from the most authoritative (characterized by direct commands) to most diffused (characterized by implicit demands) (Mann, 1986, 7-10). While territorial versions of each of these networks exist within states, we are particularly interested in the deterritorialized networks that span world society.

We do not mean to suggest that the six networks identified in Table 2 are 'the' six networks of power in world society, but we do believe that they are among the most important networks, and that they are reasonably comprehensive in encompassing a large part of 'the totality of global social interaction' (Bull, 1977, 279) that constitutes world society. Admittedly, not all social interaction involves power relationships. But power relationships are central to Mann's (and arguably Strange's) models of society, as well as to the discipline of international relations. Mann $(2013,3)$ goes so far as to claim that globalization itself is 'merely the product of expansions of the sources of social power.' Although we would not go so far as Mann in seeing society only in terms of power, and we believe that other forms of social interaction are undoubtedly important (perhaps more important) to the individuals who make up a society, we agree with Mann that power relationships are inherent in the network ties that bind society together. Power networks can thus be used to elucidate the 'common rules and institutions' of Bull's (1977, 279) world society, even if they do not necessarily identify the 'sense of common interest and common values' that underlies them.

\section{Six networks of power in world society}

In this section, we analyze each of the six deterritorialized networks of power of Table 2 from an empirical perspective. We are primarily interested in the human-to-human world society aspects of these networks. Since military power is almost by definition authoritative, we begin with the most authoritative of power networks, military/security networks. They represent, in a sense, the 
Table 2. Six deterritorialized networks of power derived from Mann (1986) and Strange (1988)

\begin{tabular}{lcc}
\hline $\begin{array}{l}\text { Our six examples of deterritorialized } \\
\text { networks }\end{array}$ & $\begin{array}{c}\text { Mann's networks of } \\
\text { power }\end{array}$ & $\begin{array}{c}\text { Strange's structures of } \\
\text { power }\end{array}$ \\
\hline $\begin{array}{l}\text { 1. Military/security } \\
\text { 2. Political }\end{array}$ & Military & Security \\
\hline 3. Economic/production & Economic & Production \\
4. Credit & & Credit \\
\hline 5. Knowledge & & Knowledge \\
\hline 6. Ideological & Ideological & \\
\hline
\end{tabular}

worst-case scenario for finding world society institutions; if we find world society even in authoritative military/security networks, we would expect to find much more of it in the more diffuse networks of civil society. We thus move from military/security networks out toward progressively more diffused networks where world society is presumably more likely to operate. Our final set of networks, ideological networks, brings us face to face with what we argue is the key primary institution of world society: networked individualism.

\section{Military/security networks}

The military/security domain is clearly one of the most important spheres of state activity; realists might say the most important. Bull's (1977) Anarchical Society was mainly dedicated to establishing the possibility of an international society of states that rests on a web of military/security networks like diplomatic alliances, balance of power, international law, great power management, and even war. Yet today's military/security networks are much more deeply rooted at the level of human-to-human interaction than were the alliance networks of the past. The most advanced of these networks is NATO, which not only conducts joint exercises involving personnel from across its 29 member states but has since its 2012 Chicago summit moved decisively toward the creation of multinational battle groups. These groups, which place troops from multiple member states in a single unit under a single commander, represent a level of human-to-human transnational military cooperation much deeper than anything exhibited in the pre-globalization era.

The multinational interoperability of NATO forces depends not only on compatible equipment and communication systems but also on shared military doctrines, which cover the nuts and bolts of everything from how to advance under covering fire from a helicopter gunship to how to triage patients in a military first aid station. Doctrines are essentially behavioral manuals that create a shared transnational culture that makes it possible for people from different countries to communicate and work together. All NATO military forces are trained to behave in line with a single set of doctrines, creating a dense network of human-to-organization-to-human ties that spans 29 countries. These ties are reinforced in the seven major NATO training facilities and a range of NATO-related Centres of Excellence, Partnership Training and Education Centres, and Partnership for Peace Defense Academies. Nor are the people educated in these institutions drawn solely from NATO countries. 
Beyond NATO, states increasingly rely on transnational epistemic communities to provide external security expertise and advice - and to legitimate, if not to outright formulate, state policy. In Europe, epistemic communities generally operate around and through treaty organizations like NATO and the European Union, which may obscure the distinction between international society and world society. Nonetheless, an epistemic community like the European Union's Permanent Structured Cooperation (PESCO) is clearly not so much a European defense treaty (international society) as an arrangement for setting common standards for infrastructure and procurement (world society, even if only at a European level). Similarly, most of Africa's military forces are educated in NATO doctrine by American and NATO ally advisors at pan-African training centers, even if that education is often poorly conducted (Jowell, 2018). In East Asia, by contrast, the military/security epistemic community operates in the absence of robust intergovernmental treaty organizations. Jerden (2017) argues that the ideological biases of members of the Asia-Pacific community of military and security experts strongly shape state behavior in favor of alliance with the United States. More broadly, even non-Western and anti-Western groupings like the Gulf Cooperation Council and the Shanghai Cooperation Organization frame their activities in terms of 'fighting terrorism' and upholding human rights, albeit their own idiosyncratic interpretations of what and whose human rights. In so doing, they implicitly accept the principle that the relevant epistemic level on which they operate is that of world society, even as they attempt to bend world society concepts to fit their own interests.

The epistemic redefinition of global security provision in terms of military cooperation against non-state actors generates demand for ever-increasing interoperability, which is often framed in light of 'global threats' (Derleth, 2015). Interoperability might indeed be seen as a primary institution of military/security world society, if it is possible to have a 'world' society that excludes the citizens of a limited number of states. Private military companies (PMCs) play a key but often overlooked (and perhaps intentionally obscured) role in shaping the 'security understandings of key actors and hence their interests and preferences' (Leander, 2005,803 ). In the military/security networks of world society, (in)security is individualized: targeted killings and PMCs are employed against recalcitrant non-state actors in ways that go beyond, challenge, or modify conventional inter-national law (Leander, 2010; Trenta, 2018). International law itself has become weaponized by both sides in asymmetric warfare pitting states against individuals and non-state actors (Irani, 2018). Put simply, wars between states are now rare; wars against individuals have become routine.

The rise of military/security world society implies a shift from the balance-ofpower politics or international society to a new world society logic of disperseand-rule (cf. Nexon, 2007, 111, who sees this as a shift from 'balance-of-power politics to logics of divide-and-rule'). Interoperability is the primary institution for this transition, as it facilitates the militarization of global action against nonstate (as opposed to state-level) actors. Although state-to-state warfighting remains an important function of the world's military forces, the shift in emphasis from international society to world society has seen the primary focus of the world's armed forces shift from state to non-state actors, from conventional interstate 
wars to Kaldor's (2015) 'new wars' of drug enforcement, anti-piracy patrols, and antiterrorism operations. Today's military/security networks are increasingly composed of and directed against individuals rather than states, shifting the center of gravity of military/security networks substantially (if not overwhelmingly) from international society to world society.

\section{Political networks}

Though not as extremely authoritative as military/security networks, political networks are also by nature authoritative, yet here too we find signs of budding world society. At least three developments distinguish political networks in world society. First, there has been a shift from 'old' state-centric diplomacy to 'new' diplomacy composed of multiple actors and networks that coalesce in various issue-areas (Cooper and Hocking, 2000; Bjola and Kornprobst, 2013, 44-60; Adler-Nissen, 2015) as the drafting of treaties increasingly involves consultation with multiple stakeholders and non-state actors (Backstrand et al., 2017). Second, there has been an increasing tendency of non-state actors to use international law as a strategic 'resource' (cf. Hurd, 2011, who views international law as strategic resource, yet a resource used by states), the interpretation of which is often ceded to the Anglo-American arbitration community (Gindin and Panitch, 2012). Third, rather than lobbying their national capitals, participants in the political networks of world society increasingly tend to seek favor in Washington, where effective power (or at least influence) is often perceived to lie (Strange, 1989, 170; Babones, 2014).

Sanctions regimes are clear examples of where all three aspects of political networks in world society converge. International sanctions, especially those imposed by the United States, have become a potent political tool (Drezner, 2015). Advocates lobby Washington to influence the make-up of sanctions, and through US law, sanctions are enforced that can cut countries off from the global financial system, international trade, access to energy resources, etc. Sanctions themselves are often focused on elite individuals and government-linked companies, rather than on countries themselves. Travel bans and bank account freezes are directed at private individuals with the purpose of influencing state action, not directed at governments, heads of state, or diplomats, who in fact continue to enjoy international travel and access to funds. Sanctions thus operate through the informal networks of structural power in world society as well as through the formal channels of relational power in international society.

Beyond sanctions, extraterritorial jurisprudence more broadly is an area where nontraditional actors are able to exert influence in the political networks of world society by leveraging public court systems to achieve private goals. Even more than in the case of sanctions regimes, it is US law, rather than formal international law, that serves as the primary lever of power. Extraterritorial US antibribery prosecutions even seem to have the effect of spurring other countries to enforce their own anti-bribery laws (Kaczmarek and Newman, 2011). The wide reach of the US Foreign Corrupt Practices Act (FCPA) is a clear example of the emerging power of extraterritorial jurisprudence (Leibold, 2014), but it is not the only one. American approaches to securities regulation have been extended to much of the world through a process of 'deliberate regulatory export' (Bach and 
Newman, 2010, 524), and the global private enforcement of American copyright law has reached epic proportions due to the global dominance of the US-based internet giants who host much of the world's digital content. Through these and similar channels, extraterritorial jurisprudence infuses derivative world society institutions like sanctions, arbitration, and jurisdiction shopping.

The global reach of political world society is perhaps best illustrated by the limited protests against it led by Russia and China. Their 2016 joint declaration asserts an international relations doctrine demanding 'a just and equitable international order' based on formal international treaties and the sovereign equality of states (MOFARF, 2016). As much as they may breach these principles in practice, Russia and China seek to use the international society principles of international law and sovereign equality as a defensive shield against extraterritorial jurisprudence and the individualization of de facto international law enforcement, which for them reflect the 'hegemonism' of the United States (Yilmaz, 2016). Russia, China, and other counter-hegemonic actors routinely decry the ongoing transformation of the 'old' political international society dominated by intergovernmental organizations into a 'new' political world society dominated by more nimble private transnational regulatory organizations (PTROs; Abbott, Green, and Keohane, 2016). As with military/security networks, global political networks may not be dominated by world society actors, but world society actors are increasingly present and powerful in these networks, and increasingly skilled at using political networks to support individual and organizational, rather than purely national, goals.

\section{Economic/production networks}

The economic globalization of the last fifty years has led to the emergence of transnational production networks in which production no longer takes place primarily in nationally contained economies, but is organized globally through different production modules in a number of countries with specialized roles in the production process. This transformation of the global economy has given rise to the concept of global value chains (GVCs), which approach the global political economy 'through the conceptual architecture of chain governance and network dynamics' (Neilson, Pritchard, and Yeung, 2014, 1). An apt way to conceive the state's role in these global production networks is as an 'inter-scalar mediator' that facilitates coupling processes between global corporations and local firms (Lee, Heo, and Kim, 2014).

A key aspect of value chain management is the power of lead firms to coordinate global value chains and the value-added activities of numerous economic actors embedded in global production networks. Central to this system-wide corporate governance is the outsourcing of peripheral, labor-intensive, low-value added productive functions to low cost locations while high-value added activities such as $\mathrm{R} \& \mathrm{D}$, design, branding, marketing, and customer service are maintained in the advanced consumer markets (Gereffi, 1994; Nolan, Zhang, and Liu, 2008). Intermediaries that primarily provide intangible service inputs, such as legal consultants, logistics services, and technical-economic networks of standard-setters also play critical roles in this new global political economy (Loconto and Busch, 2010; Coe, 2014). Yet although 'activities are widely dispersed across the globe, power is still highly concentrated' (Starrs, 2013: 819). 
In an economy organized around global and regional production networks and global value chains, trade in value-added (TiVA) becomes more important for understanding the global distribution of power and rewards than official international trade figures (Koopman et al., 2010; WTO, 2011). China hosts the world's largest manufacturing and assembly hubs, but the Chinese value-added often represents a minor share of the total value of its exports; in TiVA terms, the bulk of the value-added often accrues to foreign firms (Linden, Kraemer, and Dedrick, 2009; Dedrick, Kraemer, and Linden, 2010). As a result, China's dominance in production at the lower ends of GVCs does not translate into a central position in global economic networks. In fact, US transnational corporations continue to dominate the global political economy - and that dominance is most pronounced in hightechnology sectors. Starrs (2013) analyzed the world's 2000 largest public companies by market capitalization and found that US corporations hold the top positions in terms of profit share in 18 out of 25 sectors. In 10 of those sectors, the aggregate profit share of US corporations exceeds $40 \%$.

In the online networks at the peak of today's economic/production networks, command and control 'works through different types of governance that act upon participants "at-a-distance".' (Neil, Pritchard, and Yeung, 2014, 2). This 'at-a-distance' governance of global production networks in the virtual economy is heavily tilted towards American (or at least US-based) firms (Starrs, 2013; Schwartz, 2017b). Moreover, the transnational global corporate elite who control these firms is increasingly concentrated in the United States (Carroll, 2009; van Apeldoorn and de Graaff, 2014). Carroll and Carson (2003) conclude that the highly selective and centralized networks of the global corporate elite are not merely dealing with corporate management, but are actively engaged in business activism that seeks to promote policies that fall in line with their global-political economic interests. If the global value chain is the primary institution of the economic/production networks of world society, that society prioritizes elite companies and individuals over state institutions to such an extent that support for the corporate sector is construed as the raison d'etre of the state itself.

\section{Credit networks}

Globalization has facilitated the expansion of international monetary and credit flows to unprecedented heights. Foreign currency trading, for example, averaged $\$ 5.1$ trillion per day in 2016, which annually amounts to about 25 times global GDP (BIS, 2016, 3). Trade in various financial derivatives is several times larger still. Under the postwar Bretton Woods system of international currency exchange, individuals could not trade currencies with other individuals, and indeed the transfer of currency from one country to another was highly regulated. That world is gone. Today, nongovernmental financial flows vastly outweigh official currency transactions between governments, and private investment flows vastly outweigh state-to-state official development assistance (ODA). Even the personal remittances of migrant workers are now three times the size of ODA (World Bank, 2016).

Despite anxiety and hope about alternative economic models and new centers of governance (e.g., G20, BRICS, AIIB) following the 2008 financial crisis, today's 
credit networks remain steeply hierarchical. As Oatley et al. $(2013,148)$ conclude based on a study of network structures, 'the US is more firmly ensconced at the center of the global financial system than commonly appreciated.' Several studies demonstrate the continued dominant position of the US Dollar as the global reserve currency (e.g., Cohen-Benney, 2014; Faudot and Ponsot, 2016; Kaltenbrunner and Lysandrou, 2017) and the Dollar is one of the currencies traded in $88 \%$ of all foreign exchange transactions (BIS, 2016, 3). The US and its close ally, the United Kingdom, together account for nearly $80 \%$ of all interest rate derivatives trading, a figure that has consistently risen from less than $50 \%$ in 1995 (Fichtner, 2017, 12). As a result, the US Federal Reserve has become a de facto global lender of last resort, as demonstrated during the 2007-2009 global financial crisis, when the Fed provided nearly $\$ 4.5$ trillion of Dollar liquidity to the world's central banks to prevent a global balance of payment crisis (Tooze, 2018, 207).

The particular strength of the US/UK nexus in global monetary networks is reinforced by Anglo-American dominance in credit and finance. The US share of bond market capitalization is an astonishing $80 \%$ of the global total (Kaltenbrunner and Lysandrou, 2017, 682) and US government bonds remain the global 'safe haven' asset class in times of crisis (Hager, 2017). As Fichtner (2017, 28) puts it, 'today Anglo-American global finance - a complex amalgam of public and private authority - permeates almost every political economy in the world and influences political and economic decision-making.'

Apart from the monetary seigniorage derived from issuing debt in the form of what is, in effect, a global store of value, the United States (or rather its corporate sector) is subsidized by seigniorage in all kinds of services. There is seigniorage in the provision of technological platforms, licensing fees, intellectual property rights, and all sorts of 'club' or 'franchise' goods (Schwartz, 2017a). Licensing fees are 'virtual cash pipelines' that allow corporations, after major investments in research \& development and patent portfolios, to 'simply collect cash' (Herbert and Kinney, 2013 , 4). In 2016, the United States received around $\$ 122$ billion in earnings from licensing fees, while China received a mere $\$ 519$ million (plus another $\$ 642$ million received by Hong Kong); conversely, the United States was charged $\$ 43$ billion and China $\$ 24$ billion for the use of others' intellectual property (World Bank, 2017). Moreover, IPRs disproportionally benefit already dominant firms (Schwartz, 2017b, 238).

The various forms of seigniorage together form the primary institution through which today's credit networks are structured and governed. After four decades of financial globalization, the derivative institutions of world society credit networks like monetary seigniorage and intellectual property remain overwhelmingly concentrated in the United States (with a secondary node in the United Kingdom). Rather than posing a challenge to American centrality, globalization has led to the atrophy of national credit allocation systems as free-flowing capital has shifted into networks governed by and from the United States. As globalization has freed people (and their money) to form connections without regard for international borders, the credit networks formed by their voluntary associations have centralized around distinctly (Anglo-) American nodes. 


\section{Knowledge networks}

The possibilities of global collaboration, exchange of ideas, and knowledge transfer have never been greater than they are today. Yet even as information has become more accessible, knowledge networks have become increasingly formalized, quantified, and centralized. Universities now occupy the peak positions in global knowledge networks, far overshadowing once-premier scientific associations like the Royal Society, national academies, and civil society organizations like the Royal and National Geographic Societies. Meyer et al. (1997) put universities at the heart of world society, and subsequent research in the Stanford School has focused on the role of universities in globalizing knowledge (Munch, 2014, 1). Universities are now at the core of a system of global academic stratification that has developed hand in hand with the commodification and homogenization of higher education (Erkkila, 2016, 179).

The neoliberalization of universities and the adoption of a performance culture most clearly embodied in competition for rankings (Munch, 2014). Global ranking systems like Academic Ranking of World Universities (ARWU), first published by Shanghai Jiao Tong University and now published by Shanghai Ranking Consultancy, are increasingly used to gauge the quality and competitiveness of universities. These systems clearly indicate the 'existence of an Anglo-American academic hegemony in the early 21st century' (Jons and Hoyler, 2013, 51). The global ranking systems view the top-ranked Anglo-American elite universities 'as models to emulate, identifying their key attributes as necessary for success in the global competition for excellence in higher education' (Erkkila, 2016, 178-179; see also Allen, 2017). Whether or not Anglo-American dominance continues into the future, Anglo-American universities have set the institutional patterns that other universities increasingly seek to emulate.

Global academic competition gives rise to pressures that produce isomorphism in the form of functionally equivalent researchers that emulate American academic practices to maximize the quantitative output (Ramirez, Meyer, and Lerch, 2016). Non-US/UK universities that desire to join the global elite seek after educational alliances with the top-tiered US and UK institutions and deploy strategies that include internationalization of the curriculum, exchange programs, double degree programs, research collaborations, the attraction of star scientists, offshore operations, and the establishment of teaching and research consortia (Ishikawa, 2009; Jons and Hoyler, 2013). Beyond the academy, US intellectual dominance is reinforced by foundation centrality (Parmar, 2012, 3): the influence of American philanthropic foundations, such as the 'Big 3' (Ford, Rockefeller, and Carnegie established at the turn of the twentieth century) or the present dominance of the Bill \& Melinda Gates Foundation.

The coalescence of global knowledge networks on Anglo-American patterns is closely tied to the rise of English as 'the' global language. English is more than just a (neutral) lingua franca for world society. English is a lingua economica (global business and advertising), a lingua emotiva (global popular culture and consumerism), a lingua academica (global universities and publishing), and of course a lingua Americana (Phillipson, 2008). The internet in particular was born and has grown up as an US-dominated English-language domain. As Wikipedia notes, the 
language and location of its editors are 'very Western-centric,' yet more than Western-centric, it is US-centric as well as being extremely English-centric (Wikimedia, 2011; Konieczny, 2014). Trends in book publishing confirm this picture (Wischenbart, 2013, 16).

With global internet search and social networking (outside China's walled internet) effectively monopolized by a small number of global firms, the world increasingly sees a single version of 'the' news. Globalization has made so much information available that finding it has replaced producing it as the most important factor deciding what will be read (watched, heard), and by whom. The rewards to celebrity and the challenges of discoverability suggest that something like 'distinction' (in the sense of Bourdieu, 1984) might be the primary institution in the knowledge networks of world society, since distinction is at the heart of discoverability in the hierarchical knowledge networks of world society. The rankings culture, foundation culture, and ultimately the dominance of the English language itself might be considered derivative institutions of this primary institution.

\section{Ideological networks}

Ideological networks are the most diffuse of Mann's (1986) sources of social power and as a result the most difficult to pin down empirically. In today's multicultural world society there is a tendency to admit the legitimacy of all ideologies on an equal basis, but in many ways that admission is no more than skin-deep. For example, world society seems to admit the legitimacy of all religions, even 'invented religions' based on the backstories of contemporary science fiction films, so long as they hold genuine meaning for their adherents (Cusack, 2010, 142-149). Yet that legitimacy is readily called into question when adherents of a religion hold theological positions that conflict with the sanctity of the individual. Thus official religious communitarianism (e.g., the civil enforcement of Sharia law) is often seen as being in direct conflict with world society precepts (Walby, 2003, 537). In multicultural world society, all ideologies are equal, but some ideologies are more equal than others in setting the 'standard of civilization' (Buzan, 2014b).

In principle, the primacy of the individual would seem to put all states on an equal footing, but in practice it privileges some points of view over others, and Anglo-American points of view above all. Organizations that monitor and rate countries on their respect for human rights are disproportionately based in the United States, the United Kingdom, and closely aligned countries. Though relatively passive, the world society 'clictivism' (Halupka, 2018) of social network engagement is also embedded in a small number of global online social networks. Though there are many clicktivists on national networks like those in China and Russia, their activism is necessarily regional in reach, not global.

If the primary institution of the ideological networks of world society is individualism, the historical and structural center of those networks is to be found in the United States. Tellingly, both Russian Eurasianists (e.g., Dugin, 2012) and Chinese neo-Confucianists (e.g., Zhao, 2009) identify individualism as a distinctly American threat to the international society as such. In an international society of states, Russia, China, and other states can ally in various combinations to balance the United States and restore multipolarity to the state system. But in a world 
society of individuals, neither Russian posturing nor Chinese withdrawal is able to balance the ideological field against the structural center. Even these two champions of statism have resorted to social network activism in their efforts to remain relevant in the ideological networks of world society.

\section{The endogenization of international relations}

Susan Strange $(1988,28)$ thought US structural power would prove durable; Michael Mann $(2013,427)$ does not. Both see the question in terms of international society, not world society, though Strange comes closer to the mark when she concludes that 'the source of its power has shifted from the land and the people into control over structures of the world system' (Strange, 1988, 235). For Strange $(1989,170)$, 'authority in this nonterritorial empire is exercised directly on people not on land.' That comes very close to our conceptualization of world society. Whether it is conceived of as a 'nonterritorial empire' (Strange, 1989, 170), a 'neomedieval order' (Bull, 1977, 254-255), or even an 'American tianxia' (Babones, 2017), our analyses indicate that the actually existing power networks of world society of the twenty-first century are, as Buzan $(2018,14)$ suggests, 'strongly influenced by functional differentiation.' Going beyond Buzan and the classical English School, however, we find that world society is not just functionally differentiated but also steeply hierarchical.

Functional differentiation in international relations is the idea that power need not be concentrated in a Hobbesian leviathan state, but might instead be confounded in complicated networks in which states, organizations, and influential individuals compete and cooperate to achieve their goals. Globalization has sufficiently dissolved state containers to make such 'neomedieval' power networks possible. Yet in each of the six deterritorialized networks we examined, American institutions - though not necessarily the US state itself - occupy preeminent positions. This affirms the English School idea of functional differentiation, but with a difference. In the English School, world society has been 'associated with moral cosmopolitanism' (Williams, 2014, 132) and has been 'linked mainly to liberal cosmopolitan perspectives and to concerns about justice' (Buzan, 2014a, 16). In contrast, we see no theoretical reason to expect world society to be any more equitable than domestic societies, and no empirical evidence to suggest that it is.

The primary institutions corresponding to each of our six deterritorialized networks of power are summarized in Table 3, together with examples of derivative institutions and secondary institutions. The integrated world society circumscribed by the six primary institutions of Table 3 fits reasonably well with Bull's $(1977,279)$ test criteria: it consists (1) of global or near-global interaction networks that (2) aligning people's interests and values in ways that (3) give rise to shared institutions. It may often be that people's alignment is involuntary and that their shared institutions are unpalatable, but military interoperability, extraterritorial jurisprudence, participation in global value chains, the payment of monetary and intellectual property seigniorage, the striving for distinction in global knowledge networks, and the embrace of the dignity of the individual all meet Bull's criteria and are all relatively new in world history. 
Table 3. Six primary institutions of integrated world society networks, with examples of derivative and secondary institutions

\begin{tabular}{|c|c|c|c|}
\hline $\begin{array}{l}\text { 1. Military/ } \\
\text { security }\end{array}$ & Interoperability & $\begin{array}{l}\text { Military doctrines, joint } \\
\text { exercises, global } \\
\text { threats discourses }\end{array}$ & $\begin{array}{l}\text { NATO doctrine, RIMPAC, } \\
\text { counter-terrorism } \\
\text { collaboration }\end{array}$ \\
\hline 2. Political & $\begin{array}{l}\text { Extraterritorial } \\
\text { jurisprudence }\end{array}$ & $\begin{array}{l}\text { Sanctions, arbitration, } \\
\text { jurisdiction } \\
\text { shopping }\end{array}$ & $\begin{array}{l}\text { Iran sanctions, arbitration } \\
\text { courts, FCPA }\end{array}$ \\
\hline $\begin{array}{l}\text { 3. Economic/ } \\
\text { Production }\end{array}$ & $\begin{array}{l}\text { Global value } \\
\text { chains }\end{array}$ & $\begin{array}{l}\text { Production networks, } \\
\text { technology } \\
\text { platforms, } \\
\text { corporate elites }\end{array}$ & $\begin{array}{l}\text { Operating systems, app } \\
\text { stores, corporate } \\
\text { interlocks }\end{array}$ \\
\hline 4. Credit & Seigniorage & $\begin{array}{l}\text { Monetary seigniorage, } \\
\text { intellectual } \\
\text { property }\end{array}$ & $\begin{array}{l}\text { US Dollar, financial } \\
\text { markets, licensing fees }\end{array}$ \\
\hline 5. Knowledge & Distinction & $\begin{array}{l}\text { Rankings culture, } \\
\text { foundation culture, } \\
\text { English language }\end{array}$ & $\begin{array}{l}\text { University rankings, } \\
\text { private foundations, } \\
\text { Wikipedia }\end{array}$ \\
\hline 6. Ideological & Individualism & $\begin{array}{l}\text { Democracy, human } \\
\text { rights, rule of law }\end{array}$ & $\begin{array}{l}\text { Elections, tribunals, rights } \\
\text { discourses }\end{array}$ \\
\hline
\end{tabular}

In an integrated world society, power does not necessarily follow the logic of the past, since mobile factors of production, global financial centers, and global information and communication networks all 'challenge the geographical basis of conventional international relations theory' and erode the formerly close-fitting connection between territory and power (Agnew, 1994, 77). Whereas the relational power of states is necessarily territorial, structural power in world society is deterritorialized in global networks. Network externalities ensure that over time more and more people - and elites in even greater proportions - strive to participate in those global networks. As a result, world society is inexorably expansionary, despite the fact that individual participation in world society is, in principle, voluntary. Integrated world society incorporates individuals from all countries in an interconnected network of networks, and the United States is its central state at the intersection of those networks. The United States is rather more than the central state of a global-Western state-conglomerate (Shaw, 2000, 199-208) arising from a set of interlocking sympathies and alliances among state actors. It is the central state of the first-order global society of individual human beings, the territorial space at the heart of the deterritorialized networks of integrated world society.

Neorealist IR theory (Waltz, 1979) was developed to explain the operation of relational power in the anarchic international system associated with modernity, and it does it well (Goddard and Nexon, 2005). The early English School sought to bring order to the modern international system through its focus on the international society in which international relations (including even war) are conducted. International societies arise when states in an international system allow their actions to be circumscribed by shared norms of expected and acceptable conduct. But shared norms presuppose at least some degree of mutual understanding among competing states and their leaders. Thus Bull's $(1977,13)$ much quoted 
explanation that an international society 'exists when a group of states ... form a society in the sense that they conceive themselves to be bound by a common set of rules in their relations with one another' should be read alongside his qualification that:

'A common feature of ... historical international societies is that they were all founded upon a common culture or civilization, or at least on some of the elements of such a civilization: a common language, a common epistemology and understanding of the universe, a common religion, a common ethical code, a common aesthetic or artistic tradition' (Bull, 1977, 16).

In this 'civilizational view' of international society, 'some element of world society is a precondition to international society' (Buzan, 1993, 337). But what happens when world society expands beyond the modicum necessary to support international society? The classical English School vision that such a world society would necessarily embrace cosmopolitan values and a Kantian vision of universal solidarism is, in our view, just so much wishful thinking. Nonetheless, we do observe the existence of multiple overlapping world society power networks that have the potential to influence international society just as international society itself has the potential to influence the international system. Today's international society of putatively sovereign states is embedded within (steeply hierarchical) world society networks that together constitute Bull's 'common culture or civilization' that defines the 'common set of rules' of today's actually-existing international society. Those rules are in effect the derivative institutions of world society.

The relationship between world society and international society, as well as that between international society and the international system, can be clarified by reconfiguring Buzan's $(2001,475,2004,9)$ famous 'wheel' diagram summarizing the three traditions of English School theory. In Buzan's configuration (our Figure 1a), world society, international society, and the international system touch on and influence each other. The English School has been very effective in theorizing the boundary between the international system and international society. But it has had difficulty theorizing the boundary between the international system and world society. Buzan construes this boundary in 'imperial' and 'messianic' terms, and rightly so: to us it seems likely that world societies can only directly shape international systems at extreme historical conjunctures, for example the Mongol conquests of Genghis Khan or the Spanish conquest of the Americas. True clashes of civilizations like these are extremely rare, and now that the entire world is encompassed by a single world society, unlikely to happen again.

In the ordinary ebb and flow of international relations, we would expect world society to influence the shape of the international system mainly through its effects on international society, as depicted in our Figure 1b. Thus in our version of the English School trinity, there are usually only two relevant interfaces, not three. Our Figure $1 \mathrm{~b}$ corresponds more closely to the Stanford School model of world society, in which world society is understood as the level of society that 'allocates responsible and authoritative actorhood to nation-states' (Meyer at al., 1997, 169). This approach makes clear why the interfaces between world society and international society and between international society and the international system 


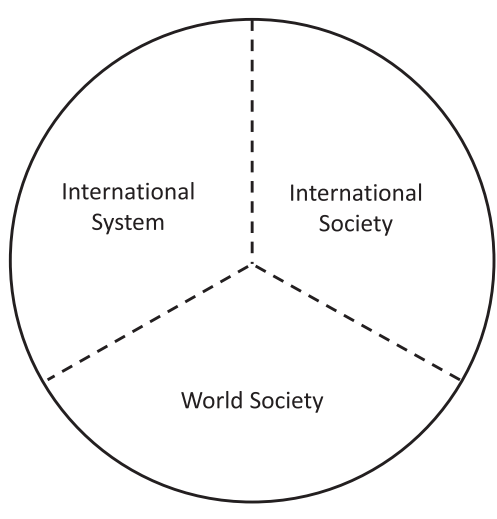

(a) "Classical" three traditions model

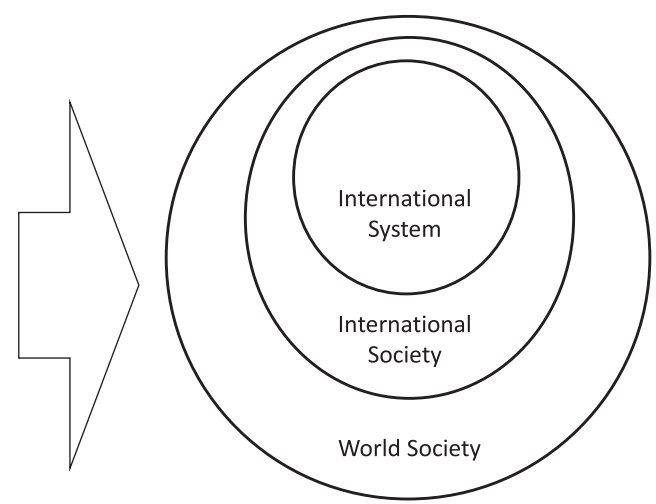

(b) Three traditions endogenization model

Figure 1. Reconfiguration of (a) Buzan's (2004, 9; 2014a, b, 14) 'classical' model of the three traditions of English School theory into (b) an endogenization model of the three traditions of English School theory.

are the interfaces that are best developed in both English School and Stanford School theory. World society sets the parameters of international society in a way analogous to that by which international society sets the parameters of the international system. As globalization has strengthened the levers of structural power in world society, it has strengthened the ability of world society to shape international society. A stronger international society has, in turn, imposed a greater degree of order on the international system and dampened its anarchical tendency toward interstate war.

The endogenization model presented in Figure $1 \mathrm{~b}$ interacts with the empirics of world society power networks to provide a framework for injecting IPE concepts of hierarchy, hegemony, and order into the English School. Wight assumed that international society would be strongest when there is an 'even distribution of power' $(1966,103)$, but the contrast between the high nineteenth century Concert of Europe and today's hierarchical international society strongly suggests that he was wrong. International society seems to be much more effective now than it was then, though it is today much farther from being a society of equals. It is effective because it is supported by a much more robust - though much less equal - world society.

Acknowledgements. We would like to express our sincere gratitude to Johan Modee, Barry Buzan, Erik Ringmar, Derek Hutcheson, and the three anonymous reviewers for insightful comments on earlier drafts.

\section{References}

Abbott, Kenneth W., Jessica F. Green, and Robert O. Keohane. 2016. "Organizational Ecology and Institutional Change in Global Governance.” International Organization 70(2):247-77.

Adler-Nissen, Rebecca. 2015. "Conclusion: Relationalism or Why Diplomats Find International Relations Theory Strange." In Diplomacy and the Making of World Politics, Edited by Ole Jacob Sending, Vincent Pouliot, and Iver Neumann, 284-308. Cambridge: Cambridge University Press.

Agnew, John. 1994. “The Territorial Trap: The Geographical Assumptions of International Relations Theory.” Review of International Political Economy 1(1):53-80. 
Albert, Mathias, and Barry Buzan. 2013. "International Relations Theory and the 'Social Whole': Encounters and Gaps Between IR and Sociology.” International Political Sociology 7(2):117-35.

Allen, Ryan M. 2017. “A Comparison of China's 'Ivy League' to Other Peer Groupings Through Global University Rankings.” Journal of Studies in International Education 21(5):395-411.

Babones, Salvatore. 2014. "From Monitory Democracy to Monitory Empire: Social Movements After Capitalism.” Oriental Institute Journal 24(2):62-71.

Babones, Salvatore. 2017. American Tianxia: Chinese Money, American Power and the End of History. Bristol: Policy Press.

Bach, David, and Abraham L. Newman. 2010. "Transgovernmental Networks and Domestic Policy Convergence: Evidence From Insider Trading Regulation.” International Organization 64(3):505-28.

Backstrand, Karin, Jonathan W. Kuyper, Bjorn-Ola Linner, and Eva Lovbrand. 2017. "Non-state Actors in Global Climate Governance: From Copenhagen to Paris and Beyond.” Environmental Politics 26(4):561-79.

BIS [Bank for International Settlements]. 2016. Triennial Central Bank Survey: Foreign Exchange Turnover in April 2016. Basel: Bank for International Settlements.

Bjola, Corneliu, and Markus Kornprobst. 2013. Understanding International Diplomacy: Theory, Practice and Ethics. New York: Routledge.

Boli, John, and George M. Thomas. 1997. "World Culture in the World Polity: A Century of International Non-Governmental Organization." American Sociological Review 62(2):171-90.

Bourdieu, Pierre. 1984. Distinction: A Social Critique of the Judgement of Taste. Cambridge: Harvard University Press.

Bull, Hedley. 1977. The Anarchical Society: A Study of Order in World Politics. London: Macmillan.

Buzan, Barry. 1993. "From International System to International Society: Structural Realism and Regime Theory Meet the English School.” International Organization 47(3):327-52.

Buzan, Barry. 2001. “The English School: An Underexploited Resource in IR.” Review of International Studies 27(3):471-88.

Buzan, Barry. 2004. From International to World Society? English School Theory and the Social Structure of Globalisation. Cambridge: Cambridge University Press.

Buzan, Barry. 2014a. An Introduction to the English School of International Relations. Cambridge: Polity Press.

Buzan, Barry. 2014b. “The ‘Standard of Civilisation’ as an English School Concept.” Millennium 42(3):576-94.

Buzan, Barry. 2018. "Revisiting World Society." International Politics 55(1):125-40.

Carroll, William K. 2009. "Transnationalists and National Networkers in the Global Corporate Elite." Global Networks 9(3):289-314.

Carroll, William K., and Colin Carson. 2003. "The Network of Global Corporations and Elite Policy Groups: A Structure for Transnational Capitalist Class Formation?” Global Networks 3(1):29-57.

Clark, Ian. 2007. International Legitimacy and World Society. Oxford: Oxford University Press.

Coe, Neil M. 2014. "Missing Links: Logistics, Governance and Upgrading in A Shifting Global Economy." Review of International Political Economy 21(1):224-56.

Cohen, Benjamin J. and Tabitha M. Benney. 2014. "What Does the International Currency System Really Look Like?” Review of International Political Economy 21(5):1017-41.

Cooper, Andrew F. and Brian Hocking. 2000. "Governments, Non-Governmental Organisations and the Re-Calibration of Diplomacy.” Global Society 14(3):361-76.

Cox, Robert W. 1981. "Social Forces, States and World Orders: Beyond International Relations Theory." Millennium 10(2):126-55.

Cusack, Carole M. 2010. Invented Religions: Imagination, Fiction and Faith. Aldershot: Ashgate.

Dedrick, Jason, Kenneth L. Kraemer, and Greg Linden. 2010. "Who Profits From Innovation in Global Value Chains? A Study of the IPod and Notebook PCs." Industrial and Corporate Change 19(1):81-116.

Derleth, James. 2015. "Enhancing Interoperability: The Foundation for Effective NATO Operations." NATO Review, June 16. Accessed December 20, 2017.

Devlen, Balkan, Patrick James, and Ozgur Ozdamar. 2005. “The English School, International Relations, and Progress.” International Studies Review 7(2):171-97.

Drezner, Daniel W. 2015. “Targeted Sanctions in A World of Global Finance." International Interactions 41(4):755-64.

Dugin, Alexander. 2012. The Fourth Political Theory. Budapest: Arktos Media. 
Erkkila, Tero. 2016. "Global University Rankings and Transnational Politics of Higher Education.” In The Transnational Politics of Higher Education: Contesting the Global/Transforming the Local, edited by Meng-Hsuan Chou, Isaac Kamola, and Tamson Pietsch, 178-95. New York: Routledge.

Faudot, Adrien, and Jean-François Ponsot. 2016. "The Dollar Dominance: Recent Episode of Trade Invoicing and Debt Issuance." Journal of Economic Integration 31(1):41-64.

Fichtner, Jan. 2017. "Perpetual Decline or Persistent Dominance? Uncovering Anglo-America's True Structural Power in Global Finance." Review of International Studies 43(1):3-28.

Gereffi, Gary. 1994. "The Organization of Buyer-Driven Global Commodity Chains: How US Retailers Shape Overseas Production Networks." In Commodity Chains and Global Capitalism, edited by Gary Gereffi and Miguel Korzeniewicz, 95-122. Westport: Praeger.

Gindin, Sam, and Leo Panitch. 2012. The Making of Global Capitalism: The Political Economy Of American Empire. London: Verso Books.

Goddard, Stacie E., and Daniel H. Nexon. 2005. "Paradigm Lost? Reassessing Theory of International Politics." European Journal of International Relations 11(1):9-61.

Hager, Sandy B. 2017. "A Global Bond: Explaining the Safe-Haven Status of US Treasury Securities." European Journal of International Relations 23(3):557-80.

Halupka, Max. 2018. “The Legitimisation of Clicktivism.” Australian Journal of Political Science 53(1):130-41.

Herbert, Zachary, and Ryan Kinney. 2013. "Qualcomm: Research Report." Check Capital Management Inc. Accessed December 12, 2017.

Hurd, Ian. 2011. "Is Humanitarian Intervention Legal? The Rule of Law in an Incoherent World." Ethics \& International Affairs 25(3):293-313.

Irani, Freya. 2018. "Lawfare', US Military Discourse, and the Colonial Constitution of Law and War." European Journal of International Security 3(1):113-33.

Ishikawa, Mayumi. 2009. "University Rankings, Global Models, and Emerging Hegemony: Critical Analysis From Japan." Journal of Studies in International Education 13(2):159-73.

Jerden, Bjorn. 2017. "Security Expertise and International Hierarchy: The Case of "The Asia-Pacific Epistemic Community”." Review of International Studies 43(3):494-515.

Jons, Heike, and Michael Hoyler. 2013. "Global Geographies of Higher Education: The Perspective of World University Rankings." Geoforum; Journal of Physical, Human, and Regional Geosciences 46 (Supplement C):45-59.

Jowell, Marco. 2018. Peacekeeping in Africa: Politics, Security, and he Failure of Foreign Military Assistance. London: I.B. Tauris.

Kaczmarek, Sarah C., and Abraham L. Newman. 2011. "The Long Arm of the Law: Extraterritoriality and the National Implementation of Foreign Bribery Legislation." International Organization 65(4):745-70.

Kaldor, Mary. 2015. New and Old Wars: Organized Violence in A Global Era. Cambridge: Polity.

Kaltenbrunner, Annina, and Photis Lysandrou. 2017. "The US Dollar's Continuing Hegemony as an International Currency: A Double-Matrix Analysis." Development and Change 48(4):663-91.

Konieczny, Piotr. 2014. "The Day Wikipedia Stood Still: Wikipedia's Editors' Participation in the 2012 Anti-SOPA Protests as A Case Study of Online Organization Empowering International and National Political Opportunity Structures." Current Sociology 62(7):994-1016.

Koopman, Robert, William Powers, Zhi Wang, and Shang-Jin Wei. 2010. "Give Credit Where Credit Is Due: Tracing Value Added in Global Production Chains." NBER Working Paper 16426.

Leander, Anna. 2005. "The Power to Construct International Security: On the Significance of Private Military Companies." Millennium 33(3):803-25.

Leander, Anna. 2010. "The Paradoxical Impunity of Private Military Companies: Authority and the Limits to Legal Accountability." Security Dialogue 41(5):467-90.

Lee, Yong-Sook, Inhye Heo, and Hyungjoo Kim. 2014. "The Role of the State as an Inter-Scalar Mediator in Globalizing Liquid Crystal Display Industry Development in South Korea." Review of International Political Economy 21(1):102-29.

Leibold, Annalisa. 2014. "Extraterritorial Application of the FCPA Under International Law." Willamette Law Review 51:225-67.

Linden, Greg, Kenneth L. Kraemer, and Jason Dedrick. 2009. "Who Captures Value in A Global Innovation Network? The Case of Apple's IPod." Communications of the ACM 52(3):140-44.

Loconto, Allison, and Lawrence Busch. 2010. "Standards, Techno-Economic Networks, and Playing Fields: Performing the Global Market Economy.” Review of International Political Economy 17(3):507-36. 
Mann, Michael. 1986. The Sources of Social Power, Volume I: A History of Power From the Beginning to A.D. 1760. Cambridge: Cambridge University Press.

Mann, Michael. 2013. The Sources of Social Power, Volume 4: Globalizations, 1945-2011. Cambridge: Cambridge University Press.

Meyer, John W., John Boli, George M. Thomas, and Francisco O. Ramirez. 1997. "World Society and the Nation-State." American Journal of Sociology 103(1):144-81.

Milanovic, Bronco. 2012. "Global Income Inequality by the Numbers: In History and Now." World Bank Policy Research Working Paper 6259.

MOFARF [Ministry of Foreign Affairs of the Russian Federation]. 2016. "The Declaration of the Russian Federation and the People's Republic of China on the Promotion of International Law." Issued June 25, 2016, Beijing.

Munch, Richard. 2014. Academic Capitalism: Universities in the Global Struggle for Excellence. New York: Routledge.

Neilson, Jeffrey, Bill Pritchard, and Henry Wai-chung Yeung. 2014. "Global Value Chains and Global Production Networks in the Changing International Political Economy: An Introduction.” Review of International Political Economy 21(1):1-8.

Nexon, Daniel H. 2007. "Discussion: American Empire and Civilizational Practice." In Civilizational Identity: The Production and Reproduction of "Civilizations" in International Relations, edited by Martin Hall and Patrick Thaddeus Jackson. New York: Palgrave Macmillan, pp. 109-16.

Nolan, Peter, Jin Zhang, and Chunhang Liu. 2008. "The Global Business Revolution, the Cascade Effect, and the Challenge for Firms From Developing Countries." Cambridge Journal of Economics 32(1):29-47.

Oatley, Thomas, W. Kindred Winecoff, Andrew Pennock, and Sarah Bauerle Danzman. 2013. "The Political Economy of Global Finance: A Network Model.” Perspectives on Politics 11(1):133-53.

Parmar, Inderjeet. 2012. "Foundation Networks and American Hegemony." European Journal of American Studies 7(1):2-25.

Phillipson, Robert. 2008. "Lingua Franca or Lingua Frankensteinia? English in European Integration and Globalisation.” World Englishes 27(2):250-67.

Ramirez, Francisco O., John W. Meyer, and Julia Lerch. 2016. "World Society and the Globalization of Educational Policy." In Handbook on Global Policy and Policy Making in Education, edited by Karen Mundy, Andy Green, Robert Lingard, and Antoni Verger, 43-63. New York: Wiley Blackwell.

Schouenborg, Laust. 2011. “A New Institutionalism? The English School as International Sociological Theory." International Relations 25(1):26-44.

Schwartz, Herman M. 2017a. "Club Goods, Intellectual Property Rights, and Profitability in the Information Economy." Business and Politics 19(2):191-214.

Schwartz, Herman M. 2017b. 'Elites and American Structural Power in the Global Economy.' International Politics 54:276-91.

Shaw, Martin. 2000. Theory of the Global State: Globality as Unfinished Revolution. Cambridge: Cambridge University Press.

Starrs, Sean. 2013. “American Economic Power Hasn't Declined-It Globalized! Summoning the Data and Taking Globalization Seriously.” International Studies Quarterly 57(4):817-30.

Strange, Susan. 1988. States and Markets. London: Pinter Publishers.

Strange, Susan. 1989. "Toward A Theory of Transnational Empire." In Global Changes and Theoretical Challenges: Approaches to World Politics for the 1990s, edited by Ernst-Otto Czempiel and James Rosenau, 161-76. Lexington: D.C. Heath and Co.

Tooze, Adam. 2018. "The Forgotten History of the Financial Crisis: What the World Should Have Learned in 2008.” Foreign Affairs 97(5):199-201.

Trenta, Luca. 2018. “The Obama Administration's Conceptual Change: Imminence and the Legitimation of Targeted Killings.” European Journal of International Security 3(1):69-93.

Tully, James, Jeffrey L. Dunoff, Anthony F. Lang, Mattias Kumm, and Antje Wiener. 2016. "Introducing Global Integral Constitutionalism.” Global Constitutionalism 5(1):1-15.

United Nations. 2000. "Millennium Declaration.” Document A/RES/55/2. New York: United Nations. van Apeldoorn, Bastiaan, and Nana de, Graaff. 2014. "Corporate Elite Networks and US Post-Cold War Grand Strategy From Clinton to Obama.” European Journal of International Relations 20(1):29-55.

Walby, Sylvia. 2003. "The Myth of the Nation-State: Theorizing Society and Polities in A Global Era." Sociology 37(3):529-46. 
Waltz, Kenneth. 1979. Theory of International Politics. Reading: Addison-Wesley Publishing Company. Wiener, Antje, Anthony F. Lang, James Tully, Miguel Poiares Maduro, and Mattias Kumm. 2012. "Global Constitutionalism: Human Rights, Democracy and the Rule of Law." Global Constitutionalism 1(1):1-15. Wight, Martin. 1966. "Western Values in International Relations." In Diplomatic Investigations: Essays in the Theory of International Politics, edited by Herbert Butterfield and Martin Wight, 89-131. London: Allen \& Unwin.

Wight, Martin. 1977. In Systems of States, edited by Hedley, Bull. Leicester: Leicester University Press.

Wight, Martin. 1992. In International Theory: The Three Traditions, edited by Gabriele Wight and Brian Porter. London: Leicester University Press.

Wikimedia. 2011. "Editors Survey 2011: Results from the Editor Survey, April 2011." Wikimedia Foundation. Accessed December 10, 2017.

Williams, John. 2014. "The International Society-World Society Distinction." In Guide to the English School in International Studies, edited by Cornelia Navari and Daniel M. Green, 127-42. Oxford: John Wiley \& Sons.

Wischenbart, Rudiger. 2013. "IPA Global Publishing Statistics." In International Publishers Association Annual Report October 2012 - October 2013, 15-21. Geneva: International Publishers Association.

World Bank. 2016. Migration and Remittances Factbook, 3rd ed. Washington: World Bank.

World Bank. 2017. World Development Indicators Databank. Washington: World Bank.

WTO [World Trade Organization]. 2011. IDE-JETRO, Trade Patterns and Global Value Chains in East Asia: From Trade in Goods to Trade in Tasks. Geneva: World Trade Organization.

Yilmaz, Serafettin. 2016. “China's Foreign Policy and Critical Theory of International Relations.” Journal of Chinese Political Science 21(1):75-88.

Zhao, Tingyang. 2009. “A Political World Philosophy in Terms of All-Under-Heaven (Tian-Xia).” Diogenes 221:5-18.

Cite this article: Babones, S., Aberg, J. H. S. 2019. "Globalization and the rise of integrated world society: deterritorialization, structural power, and the endogenization of international society." International Theory 11, 293-317, doi:10.1017/S1752971919000125 